\title{
Antimicrobial Activity of Houttuynia cordata Ethanol Extract against Major Clinical Resistant Microorganisms
}

\author{
Seung Bok Hong ${ }^{1}$ and Chun Hee Lee ${ }^{2}$ \\ ${ }^{1}$ Department of Clinical Laboratory Science, Chungbuk Health \& Science University, Cheongju 28150, Korea \\ ${ }^{2}$ Enzyme LAPA Co., Cheonnan 31114, Korea
}

\section{주요 임상 내성균에 대한 어성초 에탄올 추출물의 항균효과}

\author{
홍승복 ${ }^{1}$, 이천휘 ${ }^{2}$ \\ ${ }^{1}$ 충북보건과학대학교, ${ }^{2}$ 엔자임 라파
}

\begin{abstract}
The increase in resistance by pathogenic bacteria to multiple antimicrobial agents has become a significant treat, as the effective antimicrobial agents available for the patients infected by such resistant bacteria are reduced, or even eliminated. Several natural plant extracts have exhibited antibacterial and synergistic activity against various resistant microorganisms. Houttuynia cordata is frequently used by many traditional medicine practicioners for its antimicrobial, antiviral, and anti-inflammatory properties. This study investigated the antibacterial effects of $H$. cordata extract against clinical multi-resistant bacteria, and compared the two methods used for the antimicrobial susceptibility testing. Thirty isolates of Methicillin-resistant Staphylococcus aureus (MRSA, 10), Vancomycin-resistant Enterococcus faecium(VRE, 10), Carbapenem-resistant Acinetobacter baumannii (CRAB, 10) were included in this study. The antibacterial effect of $H$. cordata was tested by disk diffusion and microbroth dilution methods as per CLSI guidelines. In disk diffusion, all isolates (30) showed no inhibition to $30,000 \mathrm{ug} / \mathrm{mL}$ of $H$. cordata. But in the microbroth dilution method, $\mathrm{MIC}_{90}$ of $H$. cordata was 4,096 ug/mL, 8,192 ug/mL and 4,096 ug/mL in MRSA, VRE and CRAB, respectively. These results demonstrate that $H$. cordata exhibits antibacterial activity against MRSA, VRE and CRAB. Moreover, the microbroth dilution method is a more effective method than disk diffusion to evaluate the antibacterial activity of natural products. The Disk diffusion method used to evaluate the antibacterial activity of natural products required new standard guidelines including inoculum concentration of bacteria.
\end{abstract}

Keywords: Houttuynia cordata, Antibacterial activity, Microbroth dilution method, Disk diffusion method

This is an Open Access article distributed under the terms of the Creative Commons Attribution Non-Commercial License (http://creativecommons.org/licenses/by-nc/4.0) which permits unrestricted non-commercial use, distribution, and reproduction in any medium, provided the original work is properly cited.

Copyright (C 2015 The Korean Society for Clinical Laboratory Science. All rights reserved.
Corresponding author: Seung Bok Hong Department of Clinical Laboratory Science, Chungbuk Health \& Science University, Cheongju 28150, Korea Tel: 82-43-210-8308 E-mail: sbhong8646@hanmail.net

Received: August 2, 2015 Revised: August 17, 2014 Accepted: August 21, 2015

\section{서 론}

최근 methicillin-resistant Staphylococcus aureus (MRSA), vancomycin-resistant enterococci (VRE), carbapenem resistance Acinetobacter baumannii (CRAB)과 같은 다제내성 세균 의 증가가 보고되고 있으며(Kim 등, 2012; Yang 등, 2013; Chung
등, 2014), 저자들은 2004 2013년 동안 3차 의료기관 소변배양 검사결과에서 $\mathrm{MRSA}(68 \% \rightarrow 69 \%), \mathrm{VRE}(18 \% \rightarrow 26 \%)$ 그리고 $\operatorname{ESBL}(8.9 \% \rightarrow 28 \%)$ 의 의미있는 증가를 보고하였다(Hong 등, 2015). 이러한 내성세균의 증가는 감염병치료에 많은 어려움을 야기하고 있으며 전통약물 같은 천연자원에 존재하는 항균성 물질을 치료에 이용하고자 하는 연구가 활발히 수행되고 있다(Liu 등, 2000; Jo 등, 
2013). 여러 종류의 천연물질에 대한 항균효과 논문들이 많이 보고 되고 있지만 주로 대장균 또는 식중독 및 일반병원세균에 대한 논 문들이 대부분이다. 그리고 내성세균에 대한 천연물질의 항균효과 는 대부분 MRSA에 대한 연구만 보고되어 있는 실정이다(Shin과 Sung, 2006; Amin 등, 2015). 따라서 현재 임상에서 문제를 야기 하고 있는 다양한 내성균에 대한 항균효과에 대한 연구가 필요하다.

어성초(Houttuynia cordata)는 삼백초과(Saururaceae)에 속 하는 다년생 야생 약초로서 중국, 일본 및 한국에서 전통약용 식물 로 사용되며, 수종, 매독, 방광염, 자궁염, 폐렴 및 중풍 등 광범위한 지표효과가 있는 것으로 보고되고 있다(Song 등, 2003). 또한항균 (Kim 등, 2008; Cho 등, 2008), 항산화(Jeong 등, 2010), 항아토피 (Park 등, 2012), 항암(Kim 등, 2001)효과에 대한 연구들이 보고되 었다. 특히 항균에 대한 논문은 매우 많이 보고되고 있는데, 항균효 과에 사용되는 검사방법이 논문마다 상이하여 결과를 비교하기에 매우 어려움이 많다(Jang 등, 2008; Lee 등, 2011). 특히 균 접종 농 도를 표기하지 않은 경우도 있으며(Jo 등, 2013), 실험에 사용되는 천연물질의 농도 단위표기가 논문마다 다른 것을 볼 수 있었다 (Song 등, 2003; Kim 등, 2008). 이에 본 연구에서는 병원 미생물 검사실에서 통상적으로 사용되며 Clinical Laboratory Standard Institute (CLSI, 2012) 기준을 사용한 디스크 확산법과 미량액체 배지희석법을 사용하여 다제내성균에 대한 어성초의 항균효과를 측정하였다.

\section{재료 및 방법}

\section{1. 어성초 시료의 준비}

어성초는 천안 소재 고려약업사에서 구입하여 분쇄한 후 $70 \%$ 에 탄올 $100 \mathrm{~mL}$ 에 전초 $5 \mathrm{~g}$ 을 넣어 $(\mathrm{v} / \mathrm{w}) 2$ 시간 가압 가열 추출한 후 여과지(No. 2; Whatman Inc., Kent, UK)로 여과하여 진공회전농 축기(Eylya Co., Tokyo, Japan)을 이용하여 농축하고 동결 건조하 여 냉동보관 $\left(-20^{\circ} \mathrm{C}\right)$ 하면서 사용하였다. 추출된 분말은 $\mathrm{DMSO}$ 에
녹여 $100 \mathrm{mg} / \mathrm{mL}$ 로 만든 후 각 실험농도를 조정하여 사용하였다.

\section{2. 균주의 수집}

2014년 충북지역 3차 의료기관에서 S. aureus, Enterococcus faecium 및 A. baummannif를 수집하였다. 이들 균주에서 MRSA 를 선별하기 위해 $m e c A$ 유전자를, VRE를 선별하기 위해 $\operatorname{van} A$ 와 $\operatorname{van} B$ 유전자의 검출을 시도하였다. 마지막으로 $\mathrm{CRAB}$ 를 선별하기 위해 bla0xA23을 검출하였다. 최종적으로 MRSA, VRE, 및 CRAB 각 각 10 균주를 대상으로 하였다. S. aureus ATCC 29213, E. faecalis 29212, Pseudomonas aeruginosa ATCC 27853을 항균효과 검사 시 대조균주로 사용하였다. 균주의 동정은 VITEK II 자동화 장비 (bioMerieux Inc., Hazelwood, MO, USA)를 이용하였다.

\section{3. $\mathrm{PCR}$ 을 이용한 내성 유전자 검출}

\section{1) S. aureus에서 mecA 유전자 검출}

S. aureus에서 methicillin 내성유무를 결정하는 mecA 유전자 검출하여 $\mathrm{MRSA}$ 유무를 판단하였다. $m e c A$ 유전자 검출에 사용된 primer 및 조건은 Table 1과 같다.

\section{2) E. faecium에서 $\operatorname{van} A, \operatorname{van} B$ 유전자 검출}

E. faecium에서 vancomycin 내성유무를 결정하는 vanA 및 $\operatorname{vanB}$ 유전자를 검출하여 VRE 유무를 판단하였으며 이들 유전자의 검출에 사용된 primer 및 조건은 Table 1과 같다.

\section{3) A. baumann에서 bla0xA23 유전자 검출}

A. baumannii에서 carbapenemase 생성(내성) 균주를 검출하 기 위해서 blaoxa23 유전자를 이용하였으며 사용된 primer 및 조건 은 Table 1과 같다.

Table 1. Oligonucleotide primers for used in this study

\begin{tabular}{|c|c|c|c|}
\hline Primer & Target gene & Sequence $\left(5^{\prime} \rightarrow 3^{\prime}\right)$ & Reference \\
\hline $\begin{array}{l}\text { OXA23- F } \\
\text { OXA23-R }\end{array}$ & bla0XA23 & $\begin{array}{l}\text { GATCGGATTGGAGAACCAGA } \\
\text { ATTTCTGACCGCATTTCCAT }\end{array}$ & Woodford et al., 2006 \\
\hline $\begin{array}{l}\text { mecA-F } \\
\text { mecA-R }\end{array}$ & mecA & $\begin{array}{l}\text { ATGAGATTAGGCATCGTTCC } \\
\text { TGGATGACAGTACCTGAGCC }\end{array}$ & Brakstad et al., 1992 \\
\hline $\begin{array}{l}\operatorname{van} A-F \\
\operatorname{van} A-R\end{array}$ & $\operatorname{van} A$ & $\begin{array}{l}\text { GGGAAAACGACAATTGC } \\
\text { GTACAATGCGGCCGTTA }\end{array}$ & Depardieu et al., 2004 \\
\hline $\begin{array}{l}\text { vanB-F } \\
\operatorname{van} B-R\end{array}$ & $\operatorname{van} B$ & $\begin{array}{l}\text { ACGGAATGGGAAGCCGA } \\
\text { TGCACCCGTTTCGTTC }\end{array}$ & \\
\hline
\end{tabular}

Abbreviations: $F$, forward; $R$, reverse. 


\section{4. 항균효과 측정}

1) 디스크 확산법을 이용한 항균력 검사

CLSI 기준(CLSI, 2012)에 따라 혈액한천배지(BAP) 또는 MacConkey 배지에 배양 된 균을 식염수에 풀어 탁도를 McFarland 0.5 관 $\left(1.5 \times 10^{8} \mathrm{CFU} / \mathrm{mL}\right.$ )에 맞춘 후 Muller-Hinton (Asan Co, Seoul) 배지에 접종하고 빈 디스크를 올려 놓은 후 어성초 추출물을 각각 $4,096 \mu \mathrm{g} / \mathrm{mL}, 8,196 \mu \mathrm{g} / \mathrm{mL}, 10,000 \mu \mathrm{g} / \mathrm{mL}, 20,000 \mu \mathrm{g} / \mathrm{mL}$, $30,000 \mu \mathrm{g} / \mathrm{mL}$ 의 농도 $20 \mu \mathrm{L}$ 를 빈 디스크에 분주하였다. 분주 후 시료가 디스크에 스며들도록 30 분 방치 후 $35^{\circ} \mathrm{C} 18$ 시간 배양 하여 억제대의 크기를 측정하였다. 용매제의 영향 유무를 위해 $10 \%$ $\mathrm{DMSO}$ 을 시료와 동일한 조건으로 사용하였다.

\section{2) 미량액체배지 희석법을 이용한 항균력 검사}

Microplate에 어성초 $1,024 \sim 8,196 \mu \mathrm{g} / \mathrm{mL}$ 범위의 농도를 각 각 $100 \mu \mathrm{L}$ 를 넣은 후 아래농도의 균액을 넣고 $35^{\circ} \mathrm{C}$ 에서 $16 \sim 18$ 시 간 배양 후 MIC를 판독하였다(Jorgensen JH \& Turnidge, 2007). 균접종 농도는 CLSI 기준(CLSI, 2012)에 따라BAP 및 MacConkey 배지에 배양 된 균을 식염수에 풀어 탁도를 McFarland 0.5관에 맞춘 후 10 배 희석하여 $1 \times 10^{7} \mathrm{CFU} / \mathrm{mL}$ 로 만들었다. 이어서 Muller-Hinton broth에 희석하여 최종 균 농도를 $5 \times 10^{5} \mathrm{CFU} / \mathrm{mL}$ 로 하였다. 매 검사마다 S. aureus ATCC 29213, E. faecalis 29212, P. aeruginosa ATCC 27853 를 대조 균주로 사용하였다. MIC의 판독 은 어성초의 색소로 인한 육안판독이 어려워 Hong 등(2013년 대 한임상검사정도관리협회 학술연구과제 결과보고서)의 방법에 따 라 MTT (3-(4,5-dimethylthiazol-2-yl)-2,5-diphenyltetrazolium bromide) 염료를 $10 \mu \mathrm{L}$ 첨가하고 30분 방치 후 색 변화(보라색으 로 변함: 증식을 의미)를 육안으로 확인하여 증식 유무를 판독하였 다. 즉색의 변화가 나타나지 않은(균이 증식하지 못한) 최소농도를 $\mathrm{MIC}$ 로 판독하였다.

\section{결 과}

\section{1. 균주의 임상적 특징 및 내성유전자 검출}

mecA 양성 S. aureus (MRSA) 10 균주는 혈액과 소변에서 분리 되었으며 모든 균주가 oxacillin에 내성이고 vancomycin에 감수 성이었다(Table 2). Vancomcyin-resistant Enterococci는 rectal $\mathrm{swab}$ 과 소변에서 분리되었으며 모든 균주가 $\operatorname{van} A$ 를 가지고 있었 으며 vancomycin을 포함한 5종류의 항균제 모두 내성이었다 (Table 3). A. baumannii는 10 균주 모두가 bla0xa23 내성유전자를 가지고 있었으며 imipenem을 포함한 6 종류의 항균제에 내성을 보였다(Table 4).

\section{2. 항균 활성의 검사}

\section{1) 디스크 확산법을 이용한 항균력 검사}

$\mathrm{MRSA}, \mathrm{VRE}$ 및 $\mathrm{CRAB}$ 세균배양에서 $\mathrm{DMSO}$ 의 경우 억제대를 관 찰할 수 없어 어성초 추출물의 희석액으로 적절함을 확인한 후 어 성초 추출물의 희석액으로 사용하였다. MRSA 10 균주는 어성초 추출물 4,096 $\mu \mathrm{g} / \mathrm{mL}, 8,192 \mu \mathrm{g} / \mathrm{mL}, 10,000 \mu \mathrm{g} / \mathrm{mL}, 20,000$ $\mu \mathrm{g} / \mathrm{mL}, 30,000 \mu \mathrm{g} / \mathrm{mL}$ 농도를 이용한 디스크 확산법에서 억제대 가 관찰되지 않았다(Fig. 1A). CRAB 및 VRE 세균배양에서도 동일 한 결과를 보였다(Fig. 1B, 1C).

Table 2. The characteristics of methicillin-resistant Staphylococcus aureus (MRSA) and antibacterial activity of Houttuynia cordata against MRSA

\begin{tabular}{|c|c|c|c|c|c|c|c|c|c|c|c|}
\hline \multirow{2}{*}{ Strain No. } & \multirow{2}{*}{ Specimen } & \multirow{2}{*}{$\operatorname{mec} A^{*}$} & \multicolumn{7}{|c|}{ Antimicrobial susceptibility of MRSA } & \multicolumn{2}{|c|}{ Antibacterial activity of $H$. cordata } \\
\hline & & & Ox & VA & CIP & GM & $P G$ & $E$ & TE & Inhibition $(\mathrm{mm})$ by $\mathrm{DD}^{+}$ & MIC $(\mu \mathrm{g} / \mathrm{mL})$ by $\mathrm{MBD}$ \\
\hline 1 & WB & + & $R$ & S & $R$ & $\mathrm{R}$ & $R$ & $R$ & $\mathrm{R}$ & No inhibition & 4,096 \\
\hline 2 & WB & + & $\mathrm{R}$ & S & $\mathrm{R}$ & $\mathrm{R}$ & $\mathrm{R}$ & $\mathrm{R}$ & $\mathrm{R}$ & No inhibition & 4,096 \\
\hline 3 & WB & + & $\mathrm{R}$ & S & $\mathrm{R}$ & $\mathrm{R}$ & $\mathrm{R}$ & $\mathrm{R}$ & $\mathrm{R}$ & No inhibition & 4,096 \\
\hline 4 & WB & + & $\mathrm{R}$ & $\mathrm{S}$ & $R$ & $\mathrm{R}$ & $\mathrm{R}$ & $\mathrm{R}$ & $\mathrm{R}$ & No inhibition & 4,096 \\
\hline 5 & WB & + & $\mathrm{R}$ & $\mathrm{S}$ & S & $\mathrm{S}$ & $\mathrm{R}$ & $\mathrm{R}$ & $\mathrm{S}$ & No inhibition & 4,096 \\
\hline 6 & WB & + & $\mathrm{R}$ & $S$ & $R$ & $\mathrm{R}$ & $\mathrm{R}$ & $\mathrm{R}$ & $\mathrm{R}$ & No inhibition & 4,096 \\
\hline 7 & WB & + & $\mathrm{R}$ & $\mathrm{S}$ & $R$ & $\mathrm{R}$ & $\mathrm{R}$ & $R$ & $\mathrm{R}$ & No inhibition & 4,096 \\
\hline 8 & WB & + & $\mathrm{R}$ & $S$ & $\mathrm{R}$ & $\mathrm{R}$ & $\mathrm{R}$ & $\mathrm{R}$ & $\mathrm{R}$ & No inhibition & 4,096 \\
\hline 9 & urine & + & $\mathrm{R}$ & $S$ & $R$ & $\mathrm{~S}$ & $\mathrm{R}$ & $\mathrm{R}$ & $\mathrm{R}$ & No inhibition & 4,096 \\
\hline 10 & WB & + & $\mathrm{R}$ & $\mathrm{S}$ & $\mathrm{R}$ & $\mathrm{R}$ & $\mathrm{R}$ & $R$ & $\mathrm{R}$ & No inhibition & 4,096 \\
\hline$C^{\ddagger}$ & ATCC & - & S & $\mathrm{S}$ & S & $\mathrm{S}$ & S & $\mathrm{S}$ & $\mathrm{S}$ & No inhibition & 4,096 \\
\hline
\end{tabular}

Abbreviations: C, control strain; WB, whole bood; OX, oxacillin; VA, vancomycin; CIP, ciprofloxacin; GM, gentamicin; PG, penicillin G; E, erythromycin; TE, tetracycline; R, resistant; S, susceptible; DD, disk diffusion method; MBD, microbrothdilution method. *gene causing the resistance of methicillin in Staphylococcus aureus; ${ }^{\dagger}$ The concentrations of $H$. cordata ethanol extrat used were from

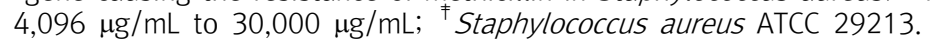


Table 3. The characteristics of vancomycin-resistant Enteroocccus faecium (VRE) and antibacterial activity of Houttuynia cordata against VRE

\begin{tabular}{|c|c|c|c|c|c|c|c|c|c|c|}
\hline \multirow{2}{*}{ Strain No. } & \multirow{2}{*}{ Speci men } & \multirow{2}{*}{$\operatorname{van} A^{*}$} & \multirow{2}{*}{$\operatorname{van} B^{\star}$} & \multicolumn{5}{|c|}{ Antimicrobial susceptibility } & \multicolumn{2}{|c|}{ Antibacterial activity of $H$. cordata } \\
\hline & & & & VA & TEI & AM & CIP & $E$ & Inhibition $(\mathrm{mm})$ by $\mathrm{DD}^{\dagger}$ & MIC $(\mu \mathrm{g} / \mathrm{mL})$ by $\mathrm{MBD}$ \\
\hline 1 & RS & + & - & $\mathrm{R}$ & $\mathrm{R}$ & $\mathrm{R}$ & $\mathrm{R}$ & $\mathrm{R}$ & No inhibition & 8,192 \\
\hline 2 & RS & + & - & $R$ & $R$ & $R$ & R & $\mathrm{R}$ & No inhibition & 4,096 \\
\hline 3 & RS & + & - & $\mathrm{R}$ & $\mathrm{R}$ & $\mathrm{R}$ & $\mathrm{R}$ & $\mathrm{R}$ & No inhibition & 4,096 \\
\hline 4 & RS & + & - & $\mathrm{R}$ & $\mathrm{R}$ & $\mathrm{R}$ & $\mathrm{R}$ & $\mathrm{R}$ & No inhibition & 4,096 \\
\hline 5 & RS & + & - & $R$ & R & $\mathrm{R}$ & R & $\mathrm{R}$ & No inhibition & 4,096 \\
\hline 6 & RS & + & - & $\mathrm{R}$ & $\mathrm{R}$ & $\mathrm{R}$ & $R$ & $\mathrm{R}$ & No inhibition & 8,192 \\
\hline 7 & RS & + & - & $\mathrm{R}$ & $R$ & $\mathrm{R}$ & $R$ & $\mathrm{R}$ & No inhibition & 8,192 \\
\hline 8 & urine & + & - & $\mathrm{R}$ & R & $\mathrm{R}$ & $\mathrm{R}$ & $\mathrm{R}$ & No inhibition & 8,192 \\
\hline 9 & urine & + & - & $\mathrm{R}$ & $\mathrm{R}$ & $\mathrm{R}$ & $R$ & $\mathrm{R}$ & No inhibition & 8,192 \\
\hline 10 & RS & + & - & $\mathrm{R}$ & $R$ & $R$ & $\mathrm{R}$ & $\mathrm{R}$ & No inhibition & 8,192 \\
\hline$C^{\ddagger}$ & ATCC & - & - & $\mathrm{S}$ & S & $\mathrm{S}$ & S & $\mathrm{S}$ & No inhibition & 8,192 \\
\hline
\end{tabular}

Abbreviations: RS, rectal swab; VA, vancomycin; TEI, teicoplanin; AM, ampicillin; CIP, ciprofloxacin; E, erythromycin; R, resistant; DD, disk diffusion method; MBD, microbrothdilution method.

${ }^{*}$ Gene causing the resistance of vancomycin in Enterococcus spp.; ${ }^{\dagger}$ The concentrations of $\mathrm{H}$. cordata ethanol extrat used were from $4,096 \mu \mathrm{g} / \mathrm{mL}$ to $30,000 \mu \mathrm{g} / \mathrm{mL}$; ${ }^{\ddagger}$ Enterococcus faecalis ATCC 29212.

Table 4. The characteristics of carbapenem-resistant Acinetobacter baumannii (CRAB) and antibacterial activity of Houttuynia cordata against CRAB

\begin{tabular}{|c|c|c|c|c|c|c|c|c|c|c|}
\hline \multirow{2}{*}{ Strain No. } & \multirow{2}{*}{ Specimen } & \multirow{2}{*}{ bla $0 \times 23^{*}$} & \multicolumn{6}{|c|}{ Antimicrobial susceptibility of MRSA } & \multicolumn{2}{|c|}{ Antibacterial activity of $H$. cordata } \\
\hline & & & IP & AK & CIP & GM & TM & $\mathrm{CTZ}$ & Inhibition $(\mathrm{mm})$ by $\mathrm{DD}^{\dagger}$ & MIC $(\mu \mathrm{g} / \mathrm{mL})$ by $\mathrm{MBD}$ \\
\hline 1 & WB & + & $\mathrm{R}$ & $\mathrm{R}$ & $\mathrm{R}$ & $\mathrm{R}$ & $\mathrm{R}$ & $\mathrm{R}$ & No inhibition & 8,192 \\
\hline 2 & SPU & + & $\mathrm{R}$ & $\mathrm{R}$ & $\mathrm{R}$ & $\mathrm{R}$ & $\mathrm{R}$ & $\mathrm{R}$ & No inhibition & 4,096 \\
\hline 3 & SPU & + & $\mathrm{R}$ & $\mathrm{R}$ & $\mathrm{R}$ & R & $R$ & $\mathrm{R}$ & No inhibition & 4,096 \\
\hline 4 & WB & + & $\mathrm{R}$ & $\mathrm{R}$ & $\mathrm{R}$ & $\mathrm{R}$ & $\mathrm{R}$ & $\mathrm{R}$ & No inhibition & 4,096 \\
\hline 5 & SPU & + & $\mathrm{R}$ & $\mathrm{R}$ & $\mathrm{R}$ & $R$ & $\mathrm{R}$ & $\mathrm{R}$ & No inhibition & 4,096 \\
\hline 6 & SPU & + & $\mathrm{R}$ & $\mathrm{R}$ & $\mathrm{R}$ & $\mathrm{R}$ & $\mathrm{R}$ & $\mathrm{R}$ & No inhibition & 4,096 \\
\hline 7 & SPU & + & $\mathrm{R}$ & $\mathrm{R}$ & $R$ & $\mathrm{R}$ & $R$ & $\mathrm{R}$ & No inhibition & 4,096 \\
\hline 8 & SPU & + & $\mathrm{R}$ & $\mathrm{R}$ & $\mathrm{R}$ & $\mathrm{R}$ & $\mathrm{R}$ & $\mathrm{R}$ & No inhibition & 4,096 \\
\hline 9 & $\mathrm{BA}$ & + & $\mathrm{R}$ & $\mathrm{R}$ & $\mathrm{R}$ & $\mathrm{R}$ & $\mathrm{R}$ & $\mathrm{R}$ & No inhibition & 4,096 \\
\hline 10 & SPU & + & $\mathrm{R}$ & $\mathrm{R}$ & $\mathrm{R}$ & $\mathrm{R}$ & $\mathrm{R}$ & $\mathrm{R}$ & No inhibition & 4,096 \\
\hline$C^{\ddagger}$ & ATCC & - & $\mathrm{S}$ & $\mathrm{S}$ & S & $\mathrm{S}$ & S & S & No inhibition & 4,096 \\
\hline
\end{tabular}

Abbreviations: WB, whole bood; SPU, sputum; BA, broncheal aspirate; IP, imipnem; AK, amikacin; CIP, ciprofloxacin; GM, gentamicin; TM, tobramycin; CTZ, ceftazidime; R, resistant; DD, disk diffusion method; MBD, microbrothdilution method.

*gene causing hydrolysis of carbapenem (eg, imipenem); ${ }^{\dagger}$ concentrations of $\mathrm{H}$. cordata ethanol extrat used were from 4,096 $\mu \mathrm{g} / \mathrm{mL}$ to $30,000 \mu \mathrm{g} / \mathrm{mL} ;{ }^{\ddagger}$ Pseudomonas aeruginosa ATCC 27853

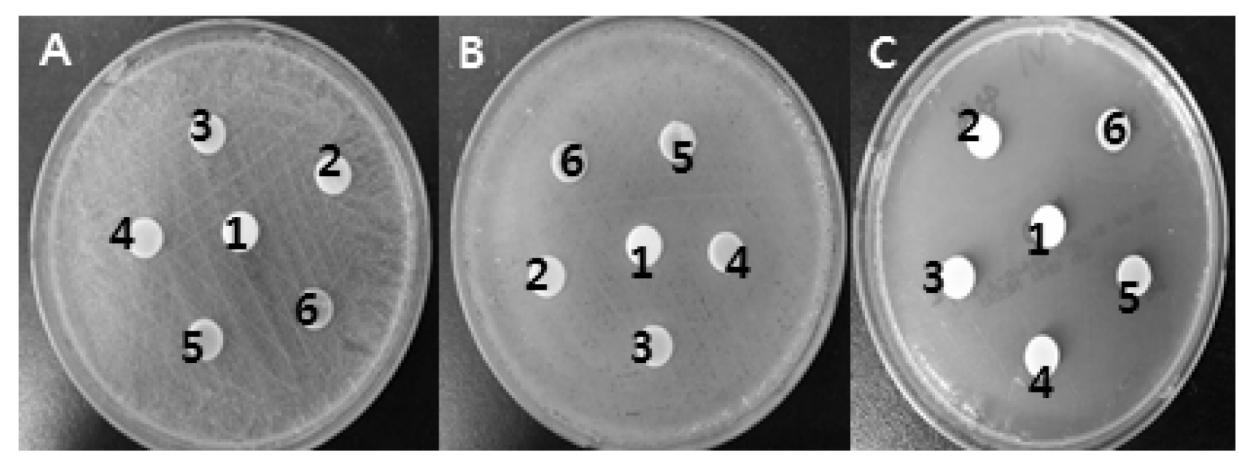

Fig. 1. Disk diffusion method of Houttuynia cordata against MRSA (A), CRAB (B) and VRE (C). Concentration of $H$. cordata ethanol extract are $10 \%$ DMSO(1), 4,096 $\mu \mathrm{g} / \mathrm{mL}$ (2), 8,196 $\mu \mathrm{g} /$ $\mathrm{mL}$ (3), $10,000 \mu \mathrm{g} / \mathrm{mL}$ (4), 20,000 $\mu \mathrm{g} / \mathrm{mL}$ (5), and 30,000 $\mu \mathrm{g} / \mathrm{mL}(6)$. All isolates showed no inhibition zone. 
Table 5. Minimal inhibitory concentration (MIC) of clinical microorganisms against Houttuynia cordata extract by microbroth dilution method

\begin{tabular}{cccc}
\hline \multirow{2}{*}{ Microorganisms (n) } & \multicolumn{3}{c}{ MIC $(\mu \mathrm{g} / \mathrm{mL})$} \\
\cline { 2 - 4 } & Range & MIC $_{50}$ & MIC $_{90}$ \\
\hline MRSA (10) & $2,048 \sim 4,096$ & 4,096 & 4,096 \\
VRE (10) & $4,096 \sim 8,192$ & 8,192 & 8,192 \\
CRAB (10) & $4,096 \sim 8,192$ & 4,096 & 4,096 \\
\hline
\end{tabular}

Abbreviations: MRSA, methicillin-resistant Staphylococcus aureus; VRE, vancomycin-resistant Enterococcus faecium; CRAB; carbapenem-resistant Acinetobacter baumannii.

\section{2) 미량액체배지 희석법을 이용한 최소억제농도(MIC)측정}

어성초 추출물에 대한 MRSA, VRE 그리고 $\mathrm{CRAB}$ 에 대한 최소억 제 농도(MIC) 결과는 Table 2, 3, 4와 같다. MTT 염료를 이용하여 색 변화를 증식여부로 판독하였으며, $\mathrm{MRSA}$ 의 $\mathrm{MIC}$ 는 2,048 $4,096 \mu \mathrm{g} / \mathrm{mL}$ 이였으며 $\mathrm{MIC}_{90}$ 은 $4,096 \mu \mathrm{g} / \mathrm{mL}$ 였다. VRE의 MIC 는 4,096 8,192 $\mu \mathrm{g} / \mathrm{mL}$ 이였으며 $\mathrm{MIC}_{90}$ 은 8,192 $\mu \mathrm{g} / \mathrm{mL}$ 였다. $\mathrm{CRAB}$ 의 MIC는 4,096 8,192 $\mu \mathrm{g} / \mathrm{mL}$ 이였으며 $\mathrm{MIC}_{90}$ 은 4,096 $\mu \mathrm{g} / \mathrm{mL}$ 였다(Table 5). 한편 대조균주로 사용한 메치실린 감수성인 S. aureus, vancomycin 감수성 E. Faecalis, imipenem 감수성 $P$. aeruginosa의 MIC는 10 개의 내성세균의 범위에 속하였다.

\section{고 찰}

내성세균의 증가는 공중 보건학적으로 커다란 문제를 야기하고 있으며, 이러한 문제를 해결하기 위해 항생물질 대체제의 개발이 중요한 대안으로 제시되고 있다(Mahady GB., 2005; Chin 등, 2008). 천연물에 대한 항균효과는 주로 디스크 확산법과 액체배지 희석법을 사용하고 있는데 국내에서는 디스크 확산법을 주로 이용 하고 있으며, 디스크 확산법과 액체배지 희석법을 병행하고 있다. 한편 국외의 경우는 액체배지 희석법으로 $\mathrm{MIC}$ 를 측정하거나 항생 제들과의 시너지효과를 측정하기도 한다(Lu 등, 2013). 본 연구에 서는 대표적인 다제내성세균인 MRSA 10 균주, VRE 10 균주 그리 고 $\mathrm{CRAB} 10$ 균주를 대상으로 어성초 에탄올 추출물의 항균효과를 측정하기 위해 병원 미생물 검사실에서 통상적으로 사용하는 CLSI 기준에 기초한 디스크 확산법과 미량약체배지희석법을 이용하였 다. CLSI 기준에 의한 McFarland 0.5관의 균농도를 이용한 디스크 확산법에서 시험균주는 4,096 $\mu \mathrm{g} / \mathrm{mL}, 8,196 \mu \mathrm{g} / \mathrm{mL}, 10,000$ $\mu \mathrm{g} / \mathrm{mL}, 20,000 \mu \mathrm{g} / \mathrm{mL}, 30,000 \mu \mathrm{g} / \mathrm{mL}$ 농도 모두에서 억제대가 관찰되지 않았다. 그러나 액체배지 희석법에서는 MRSA, VRE, $\mathrm{CRAB}$ 의 $\mathrm{MIC}_{90}$ 이 각각 $4,096 \mu \mathrm{g} / \mathrm{mL}, 8,192 \mu \mathrm{g} / \mathrm{mL}, 4,096 \mu \mathrm{g} / \mathrm{mL}$ 를 보였다(Table $2,3,4,5)$. 디스크 확산법은 액체배지 희석법보다
검사과정이 쉬우므로 많이 이용하지만 디스크 확산법에 사용하는 균농도 $\left(0.5 \mathrm{McFarland}: 1.5 \times 10^{8} \mathrm{CFU} / \mathrm{mL}\right)$ 가 액체배지 희석법의 균농도(최종농도 $1 \times 10^{5} \mathrm{CFU} / \mathrm{mL}$ )보다 높고, 천연물의 추출물이 항생제보다 항균효과가 매우 낮거나 배지에서 어성초의 확산성이 좋지 않기 때문에 억제대가 관찰되지 않았을 수 있을 것으로 사료 된다. 따라서 천연물의 항균효과 측정은 디스크 확산법보다 액체배 지 희석법으로 표준화하는 것이 좋을 것으로 사료된다. 한편 다양 한 방법으로 어성초의 항균효과에 대한 연구들이 있었는데, Kim 등(2008)은 Salmonella의 항균실험방법에서 어성초 추출물과 균 액을 섞은 후 배양하여 직접 살균효과를 보는 연구를 시행하였다. Song 등(2003)은 그람양성 및 음성균에 대한 어성초 에탄올 추출 물의 항균실험을 디스크 확산법으로 했으나 균 접종농도를 표기하 지 않고 단지 $10,000 \mu \mathrm{g}, 15,000 \mu \mathrm{g}, 20,000 \mu \mathrm{g}$ 농도에서 억제대 가 각각 $9.2 \mathrm{~mm}, 9.8 \mathrm{~mm}, 11.0 \mathrm{~mm}$ 로 항균효과가 있다고 보고하 고 있다. 또한 $\mathrm{Lu}$ 등(2006)은 어성초 에센스 오일로 $\mathrm{MIC}$ 를 측정하 여 항균효과를 보았다고 보고하였고, Lu 등(2013)은 어성초 단일 물질인 Sodium New Houttuyfonate에서 MRSA에 대한 항균효과 가 $\mathrm{MIC}_{90}$ 에서 $32 \mu \mathrm{g} / \mathrm{mL}$ 로 보고하기도 하였다. 이처럼 다양한 실 험방법을 사용하였고 균의 접종농도 및 천연물 농도를 정확히 표기 하지 않는 등 항균효과 활성 측정 방법에 대한 표준화가 되지 않아 천연물의 항균효과 정도를 논문을 통하여 비교하는 것은 매우 어렵 다. 어성초 외의 다른 천연물 항균결과들의 경우에도, Lee 등(2010) 은 에탄올 추출 승마갈근탕이 $S$. aureus 대하여 $4 \mathrm{mg} / \mathrm{disc}$ 에서 $1.40 \mathrm{~cm}$ 억제대를 보였고, MIC는 $5 \mathrm{mg} / \mathrm{mL}$ 로 보고하였다. 한편 Shin과 Sung (2006)은 백작약 추출물의 MRSA에 대한 항균효과를 $\mathrm{MIC} 50 \mathrm{mg} / \mathrm{mL}$ 이라고 보고하였으며, 디스크 확산법으로 $\mathrm{MIC}$ 를 측정하였다. 그리고 Lee 등(2011)은 마늘 추출물에서 VRE에 대해 디스크 확산법의 억제대가 $50 \%$ 농도에서 $13 \mathrm{~mm}$ 이므로 항균효과 가 있다고 보고하는 등 표준화되지 않은 다양한 방법으로 결과를 보고하고 있다.

한편 아직까지 임상에서 흔히 관찰되며 치료에서 선택할 수 있 는 항생제가 적은 $\mathrm{VRE}$ 나 $\mathrm{CRAB}$ 에 대한 어성초의 항균효과에 대한 연구는 아직 없었으나 이번 연구에서 어성초는 이들 균에 대해서도 항균효과를 보였다(Table $3,4,5)$. 앞으로 어성초 단독으로 이들 균 의 치료에 사용하기 어렵기 때문에 다양한 항균제의 상승효과에 대 한 추가 연구도 필요할 것이다(Amin 등, 2015).

결론적으로 어성초 추출물은 액체배지 희석법에 의해 주요 내성 균인 MRSA, VRE 및 $\mathrm{CRAB}$ 에서 의미 있는 항균효과를 보였다. 그 러나 디스크 확산법으로는 이들의 항균효과를 증명할 수 없었다. 따라서 천연물의 항균력을 측정할 때 디스크 확산법 보다 표준화된 액체배지 희석법이 우수하며, 만약 디스크 확산법을 이용하려면 균 
의 농도를 낮추는 등 표준화된 기준에 대한 추가적인 연구가 필요 하겠다.

\section{요 약}

다제내성균의 증가는 사용할 항생제가 적거나 심지어 선택할 항 생제가 없기 때문에 감염환자의 치료에 커다란 위협이 되고 있다. 최근 다양한 천연 추출물이 내성세균에서 항균효과 및 상승효과를 보인다는 보고가 많다. 어성초(Houttuynia cordata)는 항균, 항바 이러스 및 항산화 효과를 보이는 전통적 약초이다. 이에 저자들은 임상의 주요 내성균에 대한 어성초의 항균효과를 알아보고, 이들의 적절한 항균효과 측정방법을 평가하고자 한다. 우선 현재 가장 많 은 문제를 야기하는 주요 내성균인 methicillin-resistant Staphylococcus aureus (MRSA), vancomycin-resistant Enterococcus faecium (VRE), carbepenem-resistant Acinetobacter baumannii (CRAB) 각각 10 균주를 선택하여, CLSI 기준으로 디스크 확산법 및 미량액체배지희석법으로 감수성 시험을 하였다. CLSI 기준으로 시행한 디스크 확산법에서 4,096 $\mu \mathrm{g} / \mathrm{mL}$ 에서 $30,000 \mu \mathrm{g} / \mathrm{mL}$ 까지 의 농도에서 모든 균의 억제대는 관찰되지 않았다. 그러나 액체배 지 희석법에서는 $\mathrm{MRSA}, \mathrm{VRE}, \mathrm{CRAB}$ 의 $\mathrm{MIC}_{90}$ 이 각각 4,096 $\mu \mathrm{g} / \mathrm{mL}, 8,192 \mu \mathrm{g} / \mathrm{mL}, 4,096 \mu \mathrm{g} / \mathrm{mL}$ 를 보였다. 결론적으로 어성 초는 MRSA, VRE, CRAB 등 주요 임상 내성균에서 우수한 항균효 과를 보이며 천연물의 항균효과를 평가에 디스크 확산법보다 액체 배지 희석법이 유용하다고 할 수 있다. 만약 디스크 확산법으로 항 균효과를 측정하려면 천연물에 대한 균 접종 농도의 변경 등 새로 운 기준이 요구된다.

\section{Acknowledgements: None}

Funding: None

Conflict of interest: None

\section{References}

1. Amin MU, Khurram M, Khattak B, Khan J. Antibiotic additive and synergistic action of rutin, morin and quercetin against methicillin resistant Staphylococcus aureus. BMC Complement Altern Med. 2015, 15:59-72.

2. Brakstad OG, Aasbakk K, Maeland JA. Detection of Staphylococcus aureus by polymerase chain reaction amplication of the nuc gene. J Clin Microbiol.1992, 30: 1654-60.

3. Chin JN, Jones RN, Sader HS, Savage PB, Rybak MJ. Potential synergy activity of the novel ceragenin, CSA-13, against clinical isolates of Pseudomonas aeruginosa, including multidrug- resistant P. aeruginosa. J Antimicrob Chemother. 2008, 61:365-
370.

4. Cho WC, Kim JI, Kim MJ. Microbiological effects of xanthorrhizol and Houttuynia cordata Thunb. extract. J Korean Oil Chemists'Soc. 2008, 25:269-274.

5. Chung HS, Lee YS, Park ES, Lee DS, Ha EJ, Kim MS, et al. Characterization of the multidrug-resistant Acinetobacter species causing a nosocomial outbreak at intensive care units in a Korean teaching hospital. Ann Clin Microbiol. 2014, 17:29-34.

6. Clinical Laboratory Standards Institute. 2012. Methods for dilution antimicrobial susceptibility tests for bacteria that grow aerobically. Approved standard (M07-A9), CLSI. Wayne, PA.

7. Depardieu F, Perichon B, Courvalin P. Detection of the van alphabet and identification of Enterococci and Staphylococci at the species level by multiplex PCR. J Clin Microbiol.2004, 42: 5857-5860.

8. Hong SB, Yum JH, Kim YY, Shin KS. Trends in pathogen occurrence and antimicrobial resistance of urinary isolates in a tertiary medical center over ten years:2004 2013. Biomedical Science Letters. 2015, 21:84-91.

9. Hong SB. 2013 Academic research Report of the Korean association of quality assurance for clinical laboratory. Korean Assoc Qual Assur Clin Lab. 2013, 7-9.

10. Jang MJ, Kim YH, An BJ, Lee CE, Lee JT, Kim SH, et al. Study on anti-inflammatory and anti-microbial effect of Pinusrigida Mill. Inner bark extracts as a cosmetic material. J Korean For Soc. 2008, 97:215-220.

11. Jeong HR, Kwak JH, Kim JH, Choi GN, Jeong CH, Heo HJ. Antioxidant and neuronal cell protective effects of an extract of Houttuynia cordata Thunb. Korean J Food Preserv. 2010, 17: 720-726.

12. Jo SH, Cho CY, Ha KS, Choi EJ, Kang YR, Kwon YI. The antioxidant and antimicrobial activities of extracts of selected barley and wheat inhabited in Korean Peninsula. J Korean Soc Food Sci Nutr. 2013, 42:1003-1007.

13. Jorgensen JH, Turnidge JD. Susceptibility test methods; dilution and disk diffusion methods. In: Manual of clinical microbiology. $9^{\text {th }}$ ed, 2007, p1152-1172. ASM press, Washington, D.C.

14. Kim CH, Lee JY, Kim MK, Kim SH, Park GY, Bae SY, et al. Isolation rate of methicillin-resistant Staphphylococcus aureus (MRSA) from nasal cavity inferior regions and cellular phones. Korean J Clin Lab Sci. 2012, 44:118-123.

15. Kim DH, Lim JJ, Lee JJ, Jung WC, Shin HJ, Lee HJ, et al. Antibacterial and therapeutic effects of Houttuynia cordata ethanol extract for murine Salmonellosis. Korean J Environ Agric. 2008, 27:156-162.

16. Kim SK, Ryu SY, Choi SU, Kim YS. Cytotoxic alkaloids from Houttuynia cordata. Arch Pharm Res. 2001, 24:518-521.

17. Kim WJ, Cho JY, Choi CS, Yoon GS, Lee WK, Ryu YW. Antimicrobial activity of extracted by supercritical fluid from Origanumvulgare, Cinnamomum cassia, Chamaecyparisobtuse and Scutellariaebaicalensis. Korean J Biotechnol Bioeng. 2008, 23:147-152.

18. Lee JY, Bae HJ, Park TS, Kim TY, Moon DH, Kwon OJ, et al. Anti-oxidant and anti-microbial activities of Seungma galgeuntang. J Appl Biol Chem. 2010, 53:13-20.

19. Lee WW, Lee SM, Lee GR, Kim GH. Antimicrobial effects of galic extract against pathogenic bacteria. The annual report of 
Busan metropolitan city institution of health \& environment. 2011, 20:231-246.

20. Liu IX, DG Durham, RM Richards. Baicalin synergy with $\beta$-lactam antibiotics against methicillin-resistant Staphylococcus sureus other $\beta$-Lactam-resistant strains of $S$. aureus. J Pharm Pharmacol. 2000, 52: 361-366.

21. Lu H, Wu X, Liang Y, Zhang J. Variation in chemical composition and ntibacterial ctivities of essential oils from two species of Houttuynia Thunb. Chem Pharm Bull. 2006, 54:936-940.

22. Lu X, Yang X, Li X, Lu Y, Ren Z, Zhao L. et al. In vitro activity of sodium new Houttuyfonate alone and in combination with oXacillin or netilmicin against methicillin-resistant Staphylococcus aureus. PLOS one. 2013, 8; e68053-e68060.

23. Mahady GB. Medicinal plants for the prevention and treatment of bacterial infections. Curr Pharm Des. 2005, 11:2405-2427.

24. Park SO, Park BS, Ryu CM, Ahn YS. Effect of herb extracts mixed with Houttuynia cordata on antiatopic dermatitis in DNCB-induced BALB/c mouse. J Korean Oil Chemists'Soc. 2012, 29: 175-183.

25. Shin SH, Sung IH. Antimicrobial activities of the extracts from Paeonia japonica against MRSA. Korean J Microbiol. 2006, 42:54-58.

26. Song JH, Kim MJ, Kwon HD, Park IH. Antimicrobial activity of fractional eatracts of Houttuynia Cordara root. J Korean Soc Food Nutr. 2003, 32: 1053-1058.

27. Woodford, N., Ellington, M. J., Turton, J. F., Ward, M. E., Brown, S.,Amyes, S. G. \& Livermore, D. M. Multiplex PCR for genes encording prevalent OXA carbapenemases in Acinetobacter spp.. Int J Antimicrob Agents. 2006, 27:351-353.

28. Yang BS, Park JY, Choi SG. Rapid detection of vancomycin-resistant Enterococci (VRE) in clinical samples from university hospital. Korean J Clin Lab Sci. 2013, 45:16-20. 